\title{
Including Biodiversity Food in the Brazilian School Feeding: A Strategy to Ensure Food and Nutritional Security in Childhood
}

\author{
Camila Pia Delgado da Silva (D, Ana Laura Benevenuto de Amorim (D), \\ Daniel Henrique Bandoni $\mathbb{D}$, and Veridiana Vera de Rosso $(\mathrm{D})$
}

C. P. D. da Silva
Graduate Program in Food, Nutrition and Health, Universidade Federal de São Paulo
(UNIFESP), Santos, SP, Brazil

A. L. B. de Amorim

Interdisciplinary Graduate Program in Health Sciences, Universidade Federal de São Paulo (UNIFESP), Santos, SP, Brazil

D. H. Bandoni

Nutrition and Food Service Research Center/Department of Health, Clinic and Institutions, Universidade Federal de São Paulo (UNIFESP), Santos, SP, Brazil

V. V. de Rosso $(\square)$

Nutrition and Food Service Research Center, Universidade Federal de São Paulo (UNIFESP), Santos, SP, Brazil

e-mail: veridiana.rosso@unifesp.br

(C) The Author(s), under exclusive license to Springer Nature Switzerland AG 2021

M. C. M. Jacob, U. P. Albuquerque (eds.), Local Food Plants of Brazil,

Ethnobiology, https://doi.org/10.1007/978-3-030-69139-4_18 


\section{Introduction}

Modern agri-food systems have been based on favoring monocultures and increasing productivity, under the hegemony of transnational companies that trade seeds and inputs. Such productive model demands high energy consumption and excessive use of agricultural inputs and agrochemicals and stimulates deforestation, erosion, and soil, water, and air pollution and, above all, loss of biodiversity (Beltrame et al. 2016; Hunter et al. 2016; Tutwiler et al. 2017).

The concern with the environment and quality of life of the population has stood out in discussions on sovereignty and food and nutrition security, human right to adequate food, and foodstuff productive systems (Tutwiler et al. 2017). Food system activities appear as one of the main factors responsible for climate change, with data showing that between 2010 and 2050, the increasing world population and income will cause a 50-90\% raise in adverse environmental effects as a result of the current food system (Springmann et al. 2018). Several options for reducing the environmental effects of the food system have been pointed out, including shifts from the current diet to healthier, more plant-based ones, improvements in technology and management, and reductions in food loss and waste (Springmann et al. 2018). Springmann et al. (2018) found that no single measure is sufficient to maintain these effects within all planetary limits simultaneously and that a synergistic combination of measures will be needed to sufficiently mitigate the projected increase in environmental pressures.

In this way, redirecting the agricultural productive system toward more sustainable activities, rescuing the use of biodiversity foods, and reconnecting the rural and urban communities become a priority to boost the commercialization and consumption of these products (Ferigollo et al. 2017; Félix et al. 2018).

Generating discussion and actions on the topic of organic and agroecological production and consumption of biodiversity foods in the scope within public policies can help mitigate the impacts of monoculture, favoring the sustainable use of natural resources and the current or potential value of biodiversity foods (Scott 2017). As such, it would be possible to stimulate the production and consumption of healthy and nutritious foods, minimizing deleterious effects on the environment (Scott 2017). Biodiversity is the lifeblood of what we eat. Biodiversity - both wild and cultivated - underpins the sustainability of agricultural production by providing the genetic diversity and material needed to drive innovation and adaptation, as well as essential ecosystem services and processes (Fanzo et al. 2013).

The Brazil National School Feeding Program (PNAE), through regulations, encouraged the use of organic and agroecological foods by instituting that at least $30 \%$ of the National Education Development Fund (FNDE) be invested in the acquisition of products from family entrepreneurs and/or family farming, prioritizing organic and agroecological foods (Brasil 2009). The PNAE also encourages acquiring a diversity of foods (Brasil 2018a), obtained by planting or extractivism, either fresh or as derivatives. This strategy for promoting natural resources comes as a facilitator for a differentiated market, since it enables commercializing these foods 
at a national level, serving around 42.6 million basic education students and young people and adults in Brazil (Brasil 2013).

The encouragement by public policies for sustainable production, the use of Brazilian biodiversity, and the social inclusion of family farmers can alleviate the impacts of globalization and hegemony of the agri-food system, as well as the standardization of the menus offered to schoolchildren, guaranteeing food and nutrition security in childhood (De Paiva et al. 2012; de Sousa et al. 2015; Beltrame et al. 2016).

However, implementing the use of these foods in the Brazilian school menus can face numerous challenges, such as the regional particularities of these foods, which require developing an entire distribution chain and recipes so that food handlers know how to take advantage of the nutritional value of each biodiversity ingredient. Reason why, we believe, biodiversity foods are rarely present in Brazilian school meals.

Considering, therefore, the biological and genetic diversity existing in Brazil and the policies that encourage trade and consumption of biodiversity foods as a key to mitigate environmental, social, and nutritional problems, this study aims to evaluate the use of food species from the Brazilian biodiversity in school feeding and to discuss the main challenges for expanding the use of such foods as a strategy to guarantee student food and nutrition security.

\section{Methods}

This is a cross-sectional study developed in two stages: first, the analysis of the presence of biodiversity foods in school feeding meals from all Brazilian regions and, second, interviews with nutritionists (technical managers of the municipalities of Southeast Brazil) about acquisition of biodiversity foods.

\subsection{Analysis of the Presence of Biodiversity Foods in School Feeding Menus from All Brazilian Regions}

For analyzing the presence of biodiversity foods in school feeding menus from all Brazilian regions, we used the Efficient Manager of School Lunch Award database. This manager award, created and coordinated by the Non-Governmental Organization (NGO) Zero Hunger Action, aims to evaluate and classify how executing agencies (municipal governments) managed school meals in Brazil (Zero 2012). Launched in 2004, the last year of the award was 2013, referring to data on school feeding management in 2012.

Our study included the municipalities enrolled in the award, which sent the school feeding menus and a description of the food used. Using the 2011 School 
Feed Manager Award database, we compiled the foods mentioned in the menus sent and identified the presence of organic, regional, and biodiversity foods.

Food was classified as organic when this information appeared on the menu itself, as regional when included on the Ministry of Health list of regional foods (Brasil 2015), and as biodiversity foods when included on the Ministerial Ordinance No. 284 (Brasil 2018a), which lists species that can be acquired for school feeding as fresh or derived products.

Additionally, data on the acquisition of these foodstuffs were compiled from family farms, and we analyzed the relationship between purchase from family farming and purchase of organic, regional, and biodiversity foods.

Analyses also related city size of the cities, region of Brazil in which the city is, and use of organic, regional, and biodiversity foods. Cities were grouped according to the number of inhabitants: small size 1 (up to 20,000 inhabitants), small size 2 (from 20,001 to 50,000 inhabitants), medium size (from 50,001 to 100,000 inhabitants), and large size (over 100,001 inhabitants), adapting the Brazilian Institute of Geography and Statistics (IBGE) classification (IBGE 2018).

Data appear as relative and absolute frequencies. In order to evaluate the relationship between the variables, the chi-square was used, considering $p<0.05$ as significant. Analyses were performed in SPSS software version 17.0.

\subsection{Interviews with Nutritionists About the Acquisition of Biodiversity Food Products}

Data collection occurred from August 2014 to December 2015, involving municipalities of the four states of Southeast Brazil. All the cities of the states of São Paulo $(n=645)$, Rio de Janeiro $(n=92)$, Espírito Santo $(n=78)$, and Minas Gerais $(n=853)$ were included in the sample, totaling 1668 municipalities.

The questionnaires were sent electronically to nutritionists and/or the school feeding department of each municipality using data from the Nutritionists Registration System (SINUTRI) of the Ministry of Education/National Education Fund (FNDE).

This semi-structured questionnaire addressed general topics about the acquisition of products for composing school feeding menus in the municipality using FNDE resources and also specific topics related to the acquisition of biodiversity foods.

The variables analyzed in this stage were number of municipalities that purchased food from family farming, reasons for not buying from family farming, agricultural mapping (municipal census on agricultural production), factors prioritized by the nutritionists when preparing menus for school feeding (regional dietary habits, variety of foods in the menu, presence of biodiversity foods, and production sustainability of foods included in the menu), and description of biodiversity foods 
included in the school feeding menu and the types of preparations served using biodiversity foods.

The study was approved by the Research Ethics Committee under opinion number $1,069,621 / 2015$.

\section{Results}

\subsection{Database Analysis: Presence of Biodiversity Foods in School Feeding Menus}

Of the 1082 Brazilian cities that registered to compete for the 2011 Efficient Manager of School Lunch Award, 229 submitted their menu and were included in this study. Of these, we excluded eight cities for lacking information on food purchase from family farming, thus totaling 221 cities.

Table 1 Regional distribution and classification according to city size considering the purchase of family farming foodstuffs and the presence of organic, regional, and biodiversity foods in school feeding menus. Brazil, 2011

\begin{tabular}{|c|c|c|c|c|c|c|c|}
\hline \multirow{2}{*}{ Variables } & \multicolumn{6}{|c|}{ Family farm purchase } & \multirow[b]{2}{*}{$p^{*}$} \\
\hline & \multicolumn{2}{|c|}{ Yes $-n(\%)$} & \multicolumn{2}{|c|}{ No $-n(\%)$} & \multicolumn{2}{|c|}{ Total $-n(\%)$} & \\
\hline \multicolumn{7}{|c|}{ Regions of Brazil } & \multirow[t]{6}{*}{0.003} \\
\hline North & 3 & 42.86 & 4 & 57.14 & 7 & 3.17 & \\
\hline Northeast & 21 & 63.64 & 12 & 36.36 & 33 & 14.93 & \\
\hline Midwest & 10 & 62.50 & 6 & 37.50 & 16 & 7.24 & \\
\hline Southeast & 76 & 65.52 & 40 & 34.48 & 116 & 52.49 & \\
\hline \begin{tabular}{|l|} 
South \\
\end{tabular} & 45 & 91.84 & 4 & 8.16 & 49 & 22.17 & \\
\hline \multicolumn{7}{|l|}{ City size } & \multirow[t]{5}{*}{0.009} \\
\hline \begin{tabular}{l|l|} 
Small 1 \\
\end{tabular} & 79 & 76.70 & 24 & 23.30 & 103 & 46.61 & \\
\hline Small 2 & 41 & 68.33 & 19 & 31.67 & 60 & 27.15 & \\
\hline Medium & 22 & 75.86 & 7 & 24.14 & 29 & 13.12 & \\
\hline Large & 13 & 44.83 & 16 & 55.17 & 29 & 13.12 & \\
\hline \multicolumn{7}{|c|}{ Presence of organic foods } & \multirow[t]{3}{*}{0.008} \\
\hline Yes & 13 & 100.00 & 0 & 0.00 & 13 & 5.88 & \\
\hline No & 142 & 68.27 & 66 & 31.73 & 208 & 94.12 & \\
\hline \multicolumn{7}{|c|}{ Presence of biodiversity foods } & \multirow[t]{3}{*}{0.151} \\
\hline \begin{tabular}{l|l} 
Yes \\
\end{tabular} & 50 & 75.76 & 16 & 24.24 & 66 & 29.86 & \\
\hline No & 105 & 67.74 & 50 & 32.26 & 155 & 70.14 & \\
\hline \multicolumn{7}{|c|}{ Presence of regional foods } & \multirow[t]{3}{*}{0.072} \\
\hline \begin{tabular}{l|l} 
Yes \\
\end{tabular} & 150 & 71.43 & 60 & 28.57 & 210 & 95.02 & \\
\hline \begin{tabular}{|l|} 
No \\
\end{tabular} & 5 & 45.45 & 6 & 54.55 & 11 & 4.98 & \\
\hline Total & 155 & 70.14 & 66 & 29.86 & 221 & 100 & \\
\hline
\end{tabular}

${ }^{*} p<0.05$ (Chi-square) 
Table 1 shows the regional distribution of cities according to food purchase from family farming, classification according to city size, and presence of organic, regional, and biodiversity foods in school feeding menus. We found a significant difference when analyzing purchase from family farming by region. Thirteen $(5.88 \%)$ cities reported buying organic food from family farming, a notably low number considering the relation between family farming purchase and presence of biodiversity and regional foods, especially when obtained by extractivism. It should be noted that the menu of $210(95.02 \%)$ cities mentioned regional foods, while only $66(29.86 \%)$ menus reported using biodiversity foods.

Table 2 describes the regional foods on school menus by region, with the Southeast presenting a greater diversity of foods, followed by the Northeast and the South. The Brazilian biodiversity species mentioned in the school menus were cashew (Anacardium occidentale L.), сириас̧u (Theobroma grandiflorum K. Schum), yerba mate (Ilex paraguariensis A.St.-Hil.), passion fruit (Passiflora edulis Sims), taioba (Xanthosoma taioba E.G. Gonç.), and umbu (Spondias tuberosa Arruda).

Table 3 summarizes the data on the distribution of organic, biodiversity, and regional foods according to the cities' region. We found a significant difference between the Brazilian regions on the presence of organic and regional foods, with the South region having $11(21.57 \%)$ cities that purchased organic foodstuff, whereas in the North, Northeast, and Midwest regions, no city purchased such foods; moreover, all cities from the South region bought regional foods.

\subsection{Interviews with Nutritionists' Results About Acquisition and Use of Biodiversity Food}

We contacted all cities $(n=1668)$ from the Southeast region, and 180 participated in this study $-62.78 \%(n=113), 31.68 \%(n=57), 2.78 \%$, and $1.67 \%(n=3)$ located in the states of São Paulo, Minas Gerais, Espírito Santo, and Rio de Janeiro, respectively.

Table 2 Regional foods present in the respective regions. Brazil, 2011

\begin{tabular}{|c|c|c|c|c|}
\hline \multicolumn{5}{|c|}{ Brazilian regions } \\
\hline North & Northeast & Midwest & Southeast & South \\
\hline $\begin{array}{l}\text { Banana } \\
(\text { pacova }) \\
\text { cupuaçu } \\
(2)\end{array}$ & $\begin{array}{l}\text { Barbados cherry, } \\
\text { dwarf banana, } \\
\text { cashew, papaya, } \\
\text { passion fruit, umbu, } \\
\text { pumpkin, beans, } \\
\text { string beans, } \\
\text { cassava, cassava } \\
\text { flour, tapioca flour, } \\
\text { chives (14) }\end{array}$ & $\begin{array}{l}\text { Passion fruit, } \\
\text { pumpkin, } \\
\text { cabbage, } \\
\text { manioc, } \\
\text { green corn, } \\
\text { parsley, } \\
\text { onion (07) }\end{array}$ & $\begin{array}{l}\text { Avocado, persimmon, } \\
\text { guava, orange, mango, } \\
\text { zucchini, watercress, } \\
\text { chayote, kale, spinach, } \\
\text { bell pepper, okra, } \\
\text { cabbage, arugula, } \\
\text { taioba, pod, arracacha, } \\
\text { corn, parsley (19) }\end{array}$ & $\begin{array}{l}\text { Banana, fig, apple, } \\
\text { tangerine } \\
\text { (bergamot), grape, } \\
\text { chicory, beet, } \\
\text { cabbage, tomato, } \\
\text { lentil, potato, sweet } \\
\text { potato, cinnamon, } \\
\text { clove (14) }\end{array}$ \\
\hline
\end{tabular}


Table 3 Distribution of organic, biodiversity, and regional foods according to the regions of the country. Brazil, 2011

\begin{tabular}{|c|c|c|c|c|c|c|c|c|c|c|c|c|c|c|}
\hline \multirow{2}{*}{\multicolumn{2}{|c|}{$\begin{array}{l}\text { Regions } \\
\text { of Brazil }\end{array}$}} & \multicolumn{2}{|c|}{ North } & \multicolumn{2}{|c|}{ Northeast } & \multicolumn{2}{|c|}{ Midwest } & \multicolumn{2}{|c|}{ Southeast } & \multicolumn{2}{|c|}{ South } & \multicolumn{2}{|c|}{ Total } & \multirow[t]{2}{*}{$p^{*}$} \\
\hline & & $n$ & $\%$ & $n$ & $\%$ & $n$ & $\%$ & $n$ & $\%$ & $n$ & $\%$ & $n$ & $\%$ & \\
\hline \multicolumn{15}{|c|}{ Presence of organic foods } \\
\hline & Yes & 0 & 0 & 0 & 0 & 0 & 0 & 3 & 2.46 & 11 & 21.57 & 14 & 6.11 & \multirow[t]{2}{*}{0.000} \\
\hline & Not & 7 & 100 & 33 & 100 & 16 & 100 & 119 & 97.54 & 40 & 78.43 & 215 & 93.89 & \\
\hline \multicolumn{15}{|c|}{ Presence of biodiversity foods } \\
\hline & Tes & 2 & 28.57 & 14 & 42.42 & 7 & 43.75 & 32 & 26.23 & 12 & 23.53 & 67 & 29.26 & \multirow[t]{2}{*}{0.220} \\
\hline & Jot & 5 & 71.43 & 19 & 57.58 & 9 & 56.25 & 90 & 73.77 & 39 & 76.47 & 162 & 70.74 & \\
\hline \multicolumn{15}{|c|}{ Presence of regional foods } \\
\hline & Tes & 1 & 14.29 & 32 & 96.97 & 16 & 100 & 118 & 96.72 & 51 & 100 & 218 & 95.20 & \multirow[t]{2}{*}{0.000} \\
\hline & Jot & 6 & 85.71 & 1 & 3.03 & 0 & 0 & 4 & 3279 & 0 & 0 & 11 & 4.80 & \\
\hline Total & & 7 & 3.06 & 33 & 14.41 & 16 & 6.99 & 122 & 53.28 & 51 & 22.27 & 229 & 100 & \\
\hline
\end{tabular}

${ }^{*} p<0.05$ (Chi-square)

Of the contacted cities, $78.33 \%(n=141)$ reported acquiring food directly from family agriculture, showing low compliance with Federal Law No. 11,947 (Brasil 2009). The cities reported spending between $3 \%$ and $76.9 \%$ of the funds earmarked by the FNDE for acquiring foodstuffs from family farming.

Agricultural mapping is an efficient tool for aiding PNAE municipal managers to find suppliers of local products (Monego et al. 2013) and should include a description of local products, quantity of production, and time of harvest and/or collection. Our study found a significant difference when analyzing the relation between purchase from family farming and agricultural mapping: $58.8 \%(n=106)$ of the cities have access to agricultural mapping, of which 15 reported not buying food from family farming. Lack of information on what is regionally produced may be one of the main constraints to acquiring local production.

Nutritionists attributed the $30 \%$ non-purchase of food from family farms to the farmers' lack of interest in selling their products for school feeding, difficulty in regularizing the necessary documents, the logistical operation of delivery directly to schools, and lack of dialogue with other sectors of the city council directly involved with family farms.

Sixteen cities (8.89\%), 5 of them from the state of Minas Gerais and 11 from the state of São Paulo, reported purchasing the following biodiversity foods: "cajú," cashew apple (Anacardium occidentale Linn); "maracujá," passion fruit (Passiflora edulis Sims); "pequi” (Caryocar brasiliense Cambess); "pitanga," Brazilian cherry (Eugenia uniflora Linn); "mangaba" (Hancornia speciosa Gomes); "jabuticaba," Brazilian grape tree (Plinia cauliflora Kausel); "juçara” (Euterpe edulis Martius); "cupuaçu” (Theobroma grandiflorum Willd. ex Spreng. K. Schum); "pupunha," peach palm (Bactris gasipaes Kunth); and "urucum," achiote (Bixa Orellana Linn).

The current National School Feeding Program (Brasil 2013) norms require that the responsible nutritionist considers regional habits, variety, biodiversity, and sustainability while developing the menu. Table 4 shows how nutritionists observe this 
Table 4 Priority factors listed by nutritionists for planning the menus offered to schoolchildren. Brazil, 2015

\begin{tabular}{l|l|l|l}
\hline $\begin{array}{l}\text { Priority factors in menu } \\
\text { development }\end{array}$ & Yes $(\%-n)$ & No $(\%-n)$ & $\begin{array}{l}\text { Did not answer } \\
(\%-n)\end{array}$ \\
\hline Regional eating habits & $\begin{array}{l}90.0 \% \\
(n=162)\end{array}$ & $1.1 \%(n=2)$ & $8.9 \%(n=16)$ \\
\hline Variety of food & $\begin{array}{l}88.9 \% \\
(n=160)\end{array}$ & $2.2 \%(n=4)$ & $8.9 \%(n=16)$ \\
\hline Biodiversity & $38.9 \%(n=70)$ & $\begin{array}{l}52.2 \% \\
(n=94)\end{array}$ & $8.9 \%(n=16)$ \\
\hline Sustainability & $\begin{array}{l}60.0 \% \\
(n=108)\end{array}$ & $\begin{array}{l}31.1 \% \\
(n=56)\end{array}$ & $8.9 \%(n=16)$ \\
\hline
\end{tabular}

requirement. Although biodiversity foods can participate in regional habits, thus contributing to a varied menu, nutritionists interpreted these concepts as disassociated.

All biodiversity native fruits listed in the questionnaire feature in the Interministerial Ordinance No. 284 (Brasil 2018a), but other species could be included in the questionnaire, provided the city was making the purchase. The cities reported acquiring these fruits directly from family farming, with eight claiming to have access to agricultural mapping; thus, having access to the mapping tool allows nutritionists to know the location of family farmers and buy from them.

Nutritionists pointed out that biodiversity foods were offered on school menus as simple preparations, or only in fresh form, reducing the possibility of frequent inclusion by its use in creative and tasty recipes based on regional cuisine (de Santiago et al. 2012). Among preparations cited by nutritionists, we highlight rice with pequi and carne de sol (sun-cured meat), a traditional dish in cities of Minas Gerais (Monego et al. 2013) but also the use of some little-known fruits such as juçara, offered as a juice with banana and lemon, whose pulp is often consumed in several recipes in caiçara cuisine, typical of fishing communities (IPEMA 2012; Beltrame et al. 2016). The information on the frequency of purchase of food from the biodiversity and the supply of preparations for schoolchildren reported by study participants was incomplete.

Some municipalities offered PANCs non-conventional food plants (Plantas Alimentícias Não Convencionais) and exotic fruits (Figs. 1 and 2, respectively). PANCs have limited distribution, restricted to certain localities or regions, exerting great influence on the food and culture of traditional populations, with no productive chain organization, unlike conventional vegetables (tomato, cabbage, lettuce, etc.), not arousing commercial interest by seed, fertilizer, or agrochemical companies (Brasil 2010). 


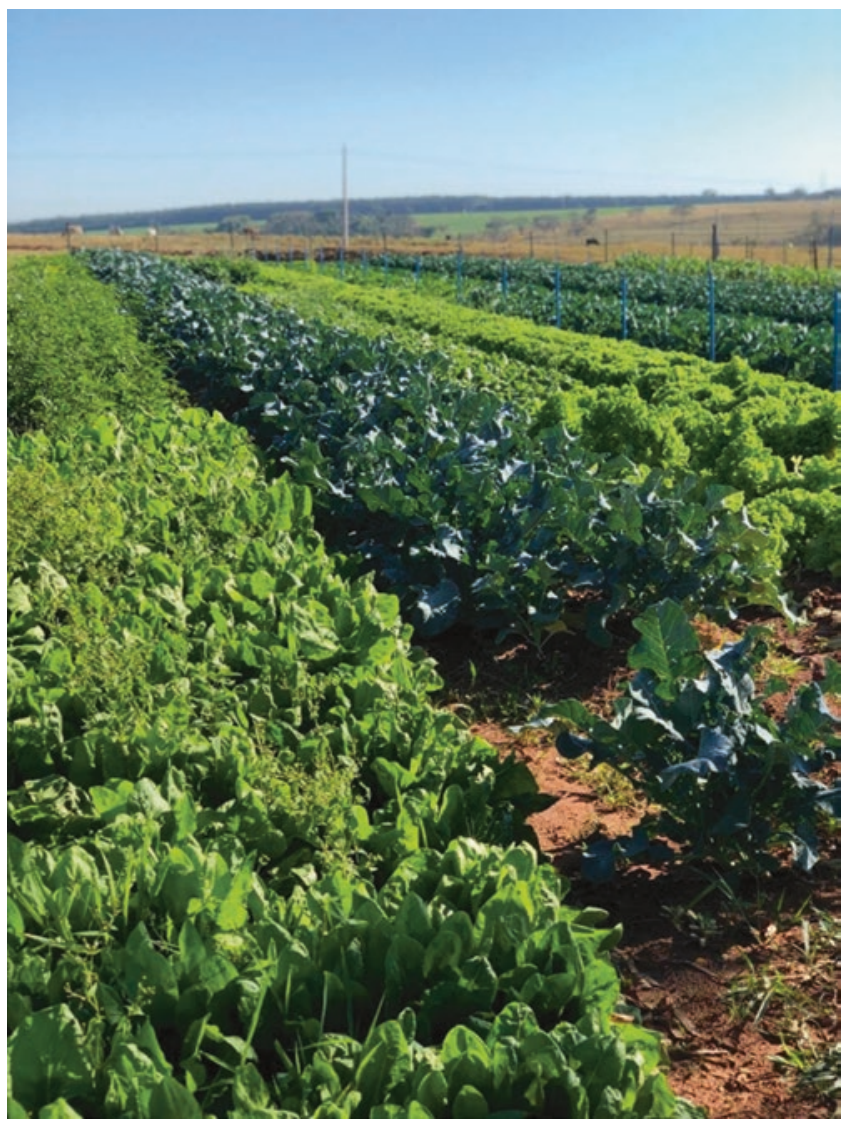

Fig. 1 Organic vegetable plantation including PANCs - non-conventional food plants

\section{Discussion}

As evidenced in the literature, the present study found a prevalence of purchase from family farming in the South region, as well as smaller municipalities (Saraiva et al. 2013; De Amorim et al. 2016), while the purchase of organic food had a positive relationship with the purchase from family farming, and thus organic food was also more present in the South region. However, there was no difference between the presence of biodiversity foods and Brazilian regions.

Despite the incentives in Brazilian legislation for school feeding regarding the purchase and use of biodiversity foods and the biomes rich in plant species of the Southeast region (REFLORA 2020), such as the Atlantic Forest and the Cerrado, our results reinforce the lack of knowledge about native regional products, reaffirming the tendency to standardize eating habits and low varied menu without local reference (de Sousa et al. 2015). This last data concerns the dissociation observed 
Fig. 2 Exotic fruit, pitaya - Hylocereus undatus Britton \& Rose

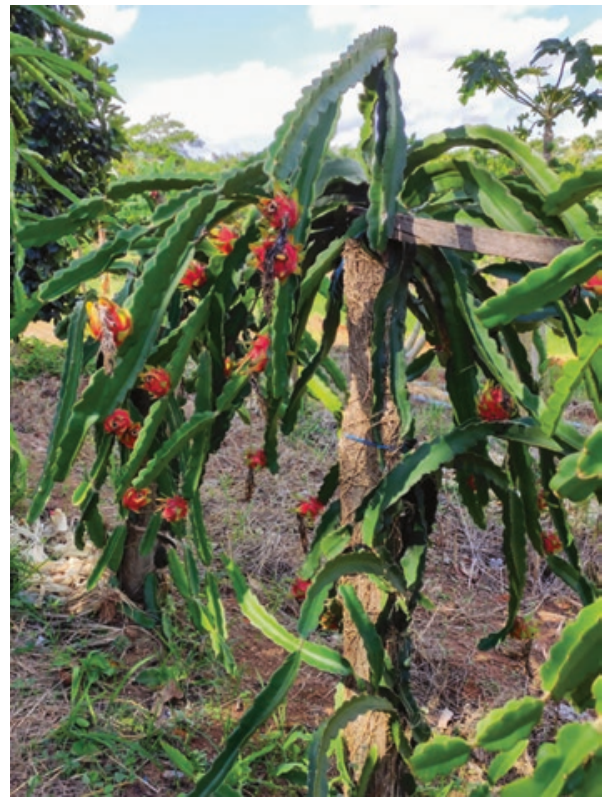

on the nutritionist's understanding of biodiversity foods, regional foods, sustainability, and varied menu.

Another limitation often pointed out by nutritionists for not including biodiversity foods in the menus is the low acceptance by schoolchildren; but (da Cunha et al. 2014) have shown that all preparations developed with regional foods, including carambola cake, green soup, jackfruit preserve, and persimmon jelly, had an acceptance of over $85 \%$ in both urban and rural schools.

The Organic Law for Food and Nutritional Security (LOSAN) proposes expanding access to food, highlighting traditional and family farming as contributors to job creation and income redistribution, identified as participatory and sustainable strategies (Brasil 2006). In parallel, PNAE requires that food be purchased from family farmers and encourages organic, agroecological, and biodiversity foods, which represents a step forward in consolidating sustainable food systems, considering the premises of the National Policy on Food and Nutritional Security (PNSAN). Moreover, it has contributed to increase the diversity and supply of quality food and to ensure the lowest transportation cost while respecting local culture and food tradition (De Sousa et al. 2009; Ferigollo et al. 2017; Schwartzman et al. 2017). The use of biodiversity foods has also proved to be efficient for sustainable food production in other parts of the world, such as the semiarid West Africa, where local management offers opportunities to collect a vast diversity of nutrient-rich species year round, supporting domestic nutrition associated with crop diversification (Félix et al. 2018).

Food purchases from family farmers have increased over the years, but a number of acquisition bottlenecks still subsist, such as bureaucratic barriers, late payment 
for farmers, limitations imposed by health, and tax legislation (Bandoni et al. 2014; Gonçalves et al. 2015). Gonçalves et al. (2015) reported that $74.1 \%$ of the cities studied in the state of São Paulo bought foodstuffs from family farmers in 2010 and 2011. We see, thus, a slow progress on procurement of family farming products for school meals between 2011 and 2015, highlighting the need to adopt new strategies such as supplying food of the biodiversity and improving the articulation between PNAE actors.

Studies addressing the acquisition and use of biodiversity foods in school meals are virtually non-existent. Amorim et al. (2016) reported that the analysis of 122 public calls made in the state of São Paulo in 2013 allowed to identify only one biodiversity species - cambuci (Campomanesia phaea Bergen).

Large cities and those located in urban centers have encountered additional difficulties regarding the logistics of receiving, storing, and distributing these foods, especially fresh produce; additionally, larger cities require larger amounts of food, which only big cooperatives can offer (de Sousa et al. 2015; De Amorim et al. 2016).

To meet future food security and sustainability needs of the world's population, food production must grow substantially; however, losses from agricultural intensification have been shown in many organisms and ecosystems, leading to their depletion and/or species extinction. As food production is the economic activity that most contributes to climate change (Springmann et al. 2018), society pushes for the consumption of food produced in systems with less environmental and human health impacts. Thus, organic and agroecological agriculture has gained space, since they supposedly reduce the negative effects of traditional agriculture, being based on the dynamic interaction between soil, plants, animals, and people, the ecosystem, and the environment (Foley et al. 2011; Winqvist et al. 2012). The correlation between family farming and organic foods corroborates other literature findings, highlighting how the inclusion of family farming in public policies involved with food security is beneficial and might serve as a model for other countries. The PNAE can strengthen food systems based on agro-ecology principles and this should be valued and referenced (Guerra et al. 2018).

Family farming food production is essential for basic food crops, representing $83 \%$ of the production of cassava, $70 \%$ of beans, $58 \%$ of milk, and $45 \%$ of corn, which are strategic for the local economy but do not contribute to increasing biodiversity food consumption (Maluf et al. 2015) since the production/extractivism of such foods is low when compared with the basic food crops. To overcome this scenario, the Ministry of Social Development and Hunger Control launched the National Plan for the Promotion of Socio-Biodiversity Product Chains in 2009, aiming to develop integrated actions for promoting and strengthening biodiversity product chains, with added value and consolidation of sustainable markets (Brasil 2017). One of its main actions was the development of the Minimum Price Guarantee Policy for Socio-Biodiversity under the coordination of the Ministry of Agriculture, Livestock and Food Supply, aimed to reduce income oscillations and ensure a minimum remuneration for producers by a direct subsidy, acting as a marker of product supply. Between 2009 and 2017, the plan invested 47 million reais (US\$12 million) in subsidies for extractive producers throughout Brazil. 
Interministerial Ordinance No. 284 (Brasil 2018a) instituted a list of biodiversity species, for marketing as fresh or derivate products, in operations conducted by the Food Acquisition Program (PAA) and the National School Feeding Program (PNAE). This facilitates purchasing food biodiversity, following the specific rules of each program. The published list of species is an important guideline for PNAE managers who often claim lack of knowledge to justify noncompliance with the norm requiring that $30 \%$ of the resources passed on to school feeding by the federal government be used to purchase family farming products.

The nutritionists often cited lack of knowledge of species and ways of preparing biodiversity foods as a crucial factor limiting their offer in the school meals served. To fill this gap, the Ministry of Environment published a cookbook named Biodiversidade Brasileira: Sabores e Aromas (Brazilian Biodiversity: Flavors and Aromas), which presents biodiversity species as ingredients of preparations and can significantly assist nutritionists in planning the school menu (de Santiago and Coradin 2018). Given this context, training for nutritionists, school food handlers, and school feeding managers is fundamental for the introduction and/or improvement of all actors about the importance of buying family farming foodstuffs, as well as acquiring organic, agroecological, and biodiversity foods.

Another difficulty reported by nutritionists is access to data on the nutritional composition of biodiversity food in traditional nutritional tables, which is another obstacle to the dietary calculation of menus. In 2018, the government released a digital database called "Biodiversidade \& Nutrição" (Biodiversity and Nutrition) (Brasil 2018b), with data on the nutritional composition of Brazilian biodiversity foods, as well as recipes using these foods as ingredients. Indeed, facilitating the access to knowledge about nutritional composition is a strategy to encourage the consumption and use of such foods.

\section{Conclusion}

Although most cities buy foodstuffs from family farming, including regional foods, biodiversity and organic foods are still rare in some regions, suggesting a needed incentive to increase consuming such foods.

Brazilian ministries and universities jointly conducted institutional actions to fill gaps that could represent limitations for using food biodiversity in school meals. These actions, implemented by laws, financial subsidies, and the development of teaching materials, allow all actors involved with the Feeding Policy and School Meals to play their roles in ensuring adequate and healthy food for Brazil's 41 million schoolchildren. Like links in a sustainable chain, providing healthier food and preserving the environment are effective ways of guaranteeing the food and nutritional security of this population group.

To strengthen institutional actions, we must carry out interventions aimed at improving the knowledge of nutritionists and school feeding managers, the 
nutritional value of biodiversity species, and the different preparations in which these foods can be served to students.

Acknowledgments The authors would like to thank the Biodiversity for Food and Nutrition (BFN) project, developed in Brazil, with support from the United Nations Environment Program (UNEP) and the Food and Agriculture Organization of the United Nations (FAO) and additional support from the CGIAR Research Program on Agriculture for Nutrition and Health (A4NH).

Conflict of Interest The authors declared no conflict of interest.

\section{References}

Bandoni DH, Stedefeldt E, de Amorim ALB et al (2014) Desafios da regulação sanitária para a segurança dos aliments adquiridos da agricultura familiar para a alimentação escolar. Rev Visa em debate 2:107-114

Beltrame DMO, Oliveira CNS, Borelli T et al (2016) Diversifying institutional food procurement opportunities and barriers for integrating biodiversity for food and nutrition in Brazil. Raizes 36:55-69

Brasil (2006) Lei ${ }^{\circ}$ 11.346. Presidência da República. Cria o Sistema Nacional de Segurança Alimentar e Nutricional - SISAN com vistas em assegurar o direito humano à alimentação adequada e dá outras providências. Brasil

Brasil (2009) Lei nº 11.947. Presidência da República. Dispõe sobre o atendimento da alimentação escolar. Brasil

Brasil (2010) Manual de hortaliças não-convencionais. Ministério da Agricultura, Pecuária e Abastecimento. Secretaria de Desenvolvimento Agropecuário e Cooperativismo, Brasilia

Brasil (2013) Resolução no 26. Ministério da Educação. Fundo Nacional de Desenvolvimento da Educação. Brasil

Brasil (2015) Alimentos Regionais Brasileitos, 2nd edn. Ministério da Saúde. Secretaria de Atenção à Saúde. Departamento de Atenção Básica, Brasil

Brasil (2017) Arranjos produtivos locais : APLs de produtos da sociobiodiversidade. Ministério do Meio Ambiente, Brasil

Brasil (2018a) Portaria Interministerial n 284. Ministério do Meio Ambiente e do Desenvolvimento Social, Brasil

Brasil (2018b) Sistema de Informação sobre a biodiversidade brasileira. Biodiversidade \& Nutrição Composição nutricional e receitas. In: Ministério do Meio Ambietnte. https://ferramentas.sibbr.gov.br/ficha/bin/view/FN/

da Cunha DT, Gonçalves HVB, de Lima AFA et al (2014) Regional food dishes in the Brazilian national school food program: acceptability and nutritional composition. Rev Nutr 27:423-434. https://doi.org/10.1590/1415-52732014000400004

De Amorim ALB, De Rosso VV, Bandoni DH (2016) Acquisition of family farm foods for school meals: analysis of public procurements within rural family farming published by the cities of São Paulo state. Rev Nutr 29:297-306. https://doi.org/10.1590/1678-98652016000200012

De Paiva JB, De Freitas MDCS, Da Silva Santos LA (2012) Hábitos alimentares regionais no Programa Nacional de Alimentação Escolar: Um estudo qualitativo em um município do sertão da Bahia. Brasil Rev Nutr 25:191-202. https://doi.org/10.1590/S1415-52732012000200002

de Santiago RAC, Coradin L (eds) (2018) Biodiversidade brasileira Sabores e Aromas. Ministério do Meio Ambiente, Secretaria de Biodiversidade

de Santiago RAC, Monego ET, de Assis JN, Zago MFC (2012) Alimentação saudável na culinária regional Alimentação saudável na culinária regional, 1 3d. Goiania 
De Sousa LM, Martins KA, Cordeiro MDM et al (2009) Alimentação escolar nas comunidades quilombolas : desafios e potencialidades School nutrition in 'quilombola' communities : challenges and opportunities. Cien Saude Colet 18:987-992

de Sousa AA, da Silva APF, de Azevedo E, Ramos MO (2015) Cardápios e sustentabilidade: Ensaio sobre as diretrizes do programa nacional de alimentação escolar. Rev Nutr 28:217-229. https://doi.org/10.1590/1415-52732015000200010

Fanzo J, Hunter D, Borelli T, Mattei F (2013) Diversifying food and diets: using agricultural biodiversity to improve nutrition and health, 1st edn. Routledge, New York.

Félix GF, Diedhiou I, Le Garff M et al (2018) Use and management of biodiversity by smallholder farmers in semi-arid West Africa. Glob Food Sec 18:76-85. https://doi.org/10.1016/j. gfs.2018.08.005

Ferigollo D, Kirsten VR, Heckler D et al (2017) Products purchased from family farming for school meals in the cities of Rio Grande do Sul. Rev Saude Publica 51(6). https://doi.org/10.1590/ S1518-8787.2017051006648

Foley JA, Ramankutty N, Brauman KA et al (2011) Solutions for a cultivated planet. Nature 478:337-342

Gonçalves HVB, da Cunha DT, Stedefeldt E, de Rosso VV (2015) Family farming products on menus in school feeding: a partnership for promoting healthy eating. Ciência Rural 45:2267-2273. https://doi.org/10.1590/0103-8478cr20150214

Guerra J, Blesh J, Filho ALS, Wittman H (2018) Caminhos para o Manejo Agroecológico através de participação no Programa Nacional de Alimentação Escolar (PNAE) em Santa Catatina, Brasil. Cad Agroecol - An do VI CLAA, X CBA e V SEMDF 13

Hunter D, Özkan I, Moura de Oliveira Beltrame D et al (2016) Enabled or disabled: is the environment right for using biodiversity to improve nutrition? Front Nutr 3:1-6. https://doi. org/10.3389/fnut.2016.00014

IBGE (2018) Consulta Classes de tamanho da população dos municípios. In: IBGE, Inst. Bras. Geogr. e Estatística -. https://ww2.ibge.gov.br/home/estatistica/populacao. Accessed 20 Aug 2018

IPEMA (2012) Culinária Juçaneira. Instituto de Permacultura e Ecovilas da Mata Atlântica (Ipema), Associação para Cultura, Meio Ambiente Cidadani (Akarui) e Petrobrás, Ubatuba

Maluf RS, Burlandy L, Santarelli M et al (2015) Agricultura sensível à nutriçâo e a promoçâo da soberanía e da segurança alimentar e nutricional no Brasil. Cienc e Saude Coletiva 20:2303-2312. https://doi.org/10.1590/1413-81232015208.14032014

Monego ET, Alexandre VP, de Sousa LM et al (2013) Produção e potencial agrícolas de alimentos destinados à alimentação escolar em Goiás e no Distrito Federal, na Região Centro-Oeste do Brasil Agricultural production and potential and foods intended for schools in Goiás and Distrito Federal, located in the Midwest Region of Brazil. Rev Nutr 26:233-241

REFLORA (2020) Plantas do Brasil: Resgate Histórico e Herbário Virtual para o Conhecimento e Conservação da Flora Brasileira. http://floradobrasil.jbrj.gov.br/reflora/PrincipalUC/ PrincipalUC.do

Saraiva EB, da Silva APF, de Sousa AA et al (2013) Panorama da compra de alimentos da agricultura familiar Para o Programa Nacional de Alimentação escolar panorama of purchasing food products from family farmers for the Brazilian School Nutrition Program. Cien Saude Colet 18:927-935. https://doi.org/10.1590/S1413-81232013001000004

Schwartzman F, Mora CAR, Bogus CM, Villar BS (2017) Antecedentes e elementos da vinculação do programa de alimentação escolar do Brasil com a agricultura familiar. Cad Saude Publica 33:1-2. https://doi.org/10.1590/0102-311X00099816

Scott P (2017) Global panel on agriculture and food systems for nutrition: food systems and diets: facing the challenges of the 21st century. Food Secur Sci Sociol Econ Food Prod Access to Food 9:653-654

Springmann M, Clark M, Mason-D'Croz D et al (2018) Options for keeping the food system within environmental limits. Nature 562:519-525 
Tutwiler A, Padulosi S, Hunter D (2017) Securing sustainable and nutritious food systems through mainstreaming agricultural biodiversity: an interdisciplinary study. Lancet 389:S22. https:// doi.org/10.1016/s0140-6736(17)31134-0

Winqvist C, Ahnström J, Bengtsson J (2012) Effects of organic farming on biodiversity and ecosystem services: taking landscape complexity into account. Ann N Y Acad Sci 1249:191-203. https://doi.org/10.1111/j.1749-6632.2011.06413.x

Zero AF (2012) Gestão Eficiente da Merenda Escolar - Histórias Gostosas de Ler e Boas de Copiar 